\title{
Bilgi Ifşası (Whistleblowing) ve Etik İkilem Üzerine Çıkarımlar
}

\author{
Inferences On Whistleblowing And Ethical Dilemmas
}

\author{
Meryem AKOĞLAN KOZAK*, Sibel ŞAHIN** \\ *Prof. Dr., Anadolu Üniversitesi İşletme Fakültesi Konaklama İşletmeciliği Bölümü, Yunusemre Kampusu, 26470, Eskişehir. \\ E-posta:mkozak@anadolu.edu.tr \\ ORCID: 0000-0003-0577-1843 \\ **Araş. Gör., Anadolu Üniversitesi İ̧̧letme Fakültesi Konaklama Işletmeciliği Bölümü, Yunusemre Kampusu, 26470 Eskişehir. \\ E-posta: sibel_sahin@anadolu.edu.tr \\ ORCID: 0000-0001-5637-9118
}

MAKALE BILGILERI

Makale işlem bilgileri:

Gönderilme tarihi: 25 Ocak 2018

Düzeltme: 1 Şubat 2018

Düzeltme: 12 Şubat 2018

Kabul: 28 Şubat 2018

Anahtar sözcükler: Bilgi ifşası, Etik,

Etik ikilem, Turizm.

\section{ARTICLE INFO}

Article history:

Submitted: 25 January 2018

Resubmitted: 1 February 2018

Resubmitted: 12 Februry 2018

Accepted: 28 February 2018

Key words: Whistleblowing, Ethic, Ethical dilemma, Tourism.

\begin{abstract}
ÖZ
Bilgi ifşası, işletmelerde yaşanan ahlâk, yasa ve etik dışı eylemlerin yetkililere bildirilmesidir. Turizm faaliyetlerinin çok kültürlü yapısı, ișletmelerin insan yoğun ve çevresel faktörlere dayalı hizmet üretimi zaman zaman turist, çalışan ve işletmeler bağlamında ifşa edilebilecek yasa ve etik dışı uygulamaları ortaya çıkarmaktadır. Kişiler sessiz kalarak bilgi ifşasının yarattığı örgütsel ve bireysel sorunlardan kaçınmaktadır. Bu bağlamda etik ikilem, bilgiyi ifşa etmek ya da etmemek arasındaki kararsızlık durumudur. Çalışmada, turizmde bilgi ifşası ve buna bağlı yaşanan etik ikilemlerle ilgili kavramsal çıkarımlara ulașılması amaçlanmaktadır. Çalıșma, etik ikilemle bilgi ifşası ilişkisini inceleyen ampirik araştırmaların gerekliliğini belirtmesi yanında, bulguların toplu bakış açısıyla değerlendirilmesini sağlaması açısından da önemlidir. Bu amaçla, bilgi ifşası ve etik ikilem alanyazınındaki araștırmalar incelenmiștir. Sonuç olarak, turizmde ifşa davranıșı, bireysel ve örgütsel eğilim, örgüt içi iletișim, işini kaybetme korkusu ve çevresel duyarlılıklara göre ortaya çıkarken etik sorunlar ise genellikle işletme içi, çevre koruması ve insan ilişkilerinde ortaya çıkmaktadır. Etik ikileme yönelik bir bulguya ise rastlanmamıştır.
\end{abstract}

\begin{abstract}
Whistleblowing can be defined as notification of immoral, illegal and unethical actions that happen in enterprises to respective authorities. Multicultural structure of tourism activities and production of service based on people and environmental factors occasionally lead to illegal and unethical aplications in terms of tourist, employees and enterprises. People keep silent and avoid from indivual and organizational problems caused by whistleblowing. In this context, ethical dilemma can be stated as indecision in terms of whether to blow the whistle. In the study, it is aimed to achieve conceptual implications related to whistleblowing in tourism and ethical dilemmas. The study is important due to indicating the necessity of empirical researches which examine the relationship between ethical dilemma and whistleblowing, and providing evaluation from integrated perspective. With this aim, a literature review was conducted in the fields of whistleblowing and ethical dilemma. As a result, while the whistleblowing behaviour in tourism depends on indivudual and organizational tendency, communication climate in the organization, fear of job loss and environmental sensitivities, ethical problems mostly occur in human relations, enviromental protection and intrabusiness. Addionally, there is not any finding obtained about ethical dilemma.
\end{abstract}

\section{Giriş}

Bilgi ifşası, en kısa tanımıyla örgüt içinde ahlaka aykırı birtakım davranışların, örgüt üyeleri tarafından açıklanması anlamına gelmektedir (King 1999: 315). İşletmelerin amaçlarına ulaşmada engel teşkil edecek yasa dişı, etik dışı veya ahlak dışı olumsuz durumların işletme içinde veya dişında bulunan yetkili kişilere bildirilme- si, bireysel, örgütsel ve toplumsal düzeyde önem taşımaktadır. İşletmelerde meydana gelen yanlış uygulamaların önüne geçilmesine ilişkin etkili bir yöntem olarak ifade edilen bilgi ifşası kamu ya da özel olarak bir ayrım olmaksızın tüm işletmelerde görülebilmektedir. Bununla birlikte, toplumda bilgi ifşasında bulunan kişiye karşı olumsuz bir algı oluşmakta ve yaptırımlar uygulanmaktadir. 
Turizm alanyazınında ve sektörde etik sorunlar sıklıkla ele alınmasına rağmen, yaşanan etik ikilem durumuna ilişkin doğrudan bir araştırma bulgusuna rastlanamamıştır. İlgili alanyazında etik sorunlar ve çözüm önerileri açıklanırken yaşanan zorluklar ve engellerden bahsedilmektedir. Buradan aslında örtülü bir etik ikilem durumu yaşandığı çıkartılabilir. Bilindiği gibi turizm sektöründe insan ilişkileri yoğundur ve işletme paydaşları çok çeşitlidir. Bu fazla ilişki ağının her zaman iyi yönetilememesi, sık sık etik sorunların ortaya çıkmasına neden olmaktadır. Aldatıcı ve yanıltıcı nitelikteki tanıtıcı bilgiler, fiyatlandırma, fazladan rezervasyon, genel ahlak kurallarına aykırı eğlence türleri, sosyal ve kültürel farklılıklardan doğan uygulamalar ve bunlara ek olarak, turizm alanında sıklıkla adı geçen getiri yönetimi ile ilgili sorunlar, iş ve işveren ilişkilerinde çalışanların haklarının korunmaması, kaçak işçi çalıştırma, rüşvet, fonların yasa dışı yollardan transferi, alkol ve uyuşturucu kullanımı, bahşişlerin gelir olarak kayda geçmemesi dikkat çeken diğer etik sorunlardır (Akan 2007: 10). Bu tür etik sorunların giderilmesi için kişi/kişilerin her zaman yetkili kişiler olmayacağ 1 düşünüldüğünde, bu sorunların ya işletme içinde ya da işletme dışındaki kişilere/kurumlara bildirilmesi gerekmektedir. Bilgi ifşası veya "whistleblowing" olarak bilinen bir sorun bildirme eyleminde bulunma ya da bulunmama kararı/kararsızlığı ise aslında, bir etik ikilemdir. Çünkü bu süreçte kişi, bu sorunu bildirmek istese de işten çıkarılma, dışlanma, tehdit alma gibi istenmeyen durumlarla karşı karşıya kalacaktır. Durumun böyle bir önem ve hassasiyet arz etmesine bağlı olarak planlanan bu çalışmada, öncelikle ifşa ve etik konusu turizm alanyazını üzerinden ele alınacaktır.

Bu amaçla çalışmada, öncelikle, turizmde bilgi ifşa etme ve turizmde etik alanyazınında yer alan çalışmalar gözden geçirilerek, incelenen konuların ağırlıklı olarak hangi alanlarda topladığına bakılmıştır. Etik sorun ve konu ile ilgili çözüm önerileri bağlamında çok sayıdaki çalışmaya rağmen, bilgi ifşası sürecinde yaşanan etik ikilem konusunun doğrudan incelendiği bir araştırma bulgusuna rastlanmamıştır. Ancak, konuyla ilgili diğer alanlardaki ikilem çalışmaları ve turizmde yaşanan etik sorunlar konusu birlikte değerlen- dirilerek, ifşa etme/etmeme eksenindeki etik ikilem durumuna dikkat çekmeye çalışılacaktır.

\section{BiLGi IFŞASI (WHISTLEBLOWING) KAVRAMI}

Whistleblowing kavramı, ilk kez 1963 yılında hukuki bir belgede kullanılmıştır. Sözcügün kökeninde İngiliz polislerinin suç olaylarına karşı halkı ve diğer polisleri uyarmak için düdük çalması yatmaktadır (Hersh 2002: 243). Whistleblowing kavramının ortaya çıkmasında Enron'da şirket çalışanlarının, çalıştıkları şirkette yapılan muhasebe hilelerini ortaya çıarmasının etkisi büyüktür. Yaşanan bu olaydan sonra akademik alanyazında kavramla ilgili çalışmalar yoğunluk kazanmaya başlamıştır. Whistleblowing yabancı alanyazında "yanlış uygulamalar" şeklinde karşılık bulan "organizational wrongdoing", "organizational misconduct", "malpractise" gibi kavramlarla da ifade edilmektedir (Aktan 2006: 1). Gerçek (2005: 30) bilgi ifşasının; iddia edilen bir suçu (sahtekârlık, hırsızlık), ayrımcılığı (ırk, din, milliyet, cinsiyet vb.), bir yasaya, bir düzenlemeye, bir devlet politikasına, ahlaki değerlere, etik kurallara veya terbiyeye aykırı durumu veya toplum sağlığını ve güvenliğini tehlikeye sokan durumları açığa çıkarmak için yapıldığını ifade etmektedir. TDK "suçlu saydığı birini veya suç sayd1$\breve{g}_{1}$ bir olayı yetkili makama gizlice bildirme, ele verme" olarak tanımlamakta ve ihbar kavramını ise "gizli bir şeyi açığa çıkarma, yayma" olarak açıklamaktadır (T.C. Başbakanlık Atatürk Kültür, Dil ve Tarih Yüksek Kurumu Türk Dil Kurumu 2018). İki benzer tanım dikkatlice incelendiğinde Türkçede ifşa ile ihbar kavramlarının benzer oldukları ve birbirlerinin yerine kullanılabileceği söylenebilir. Her iki kavramın açıklanmasında da suç duyuru yanında, etik dışı ve ahlak d1şı durumlara da vurgu yapıldığı görülmektedir. Bu bilgilere dayanarak bu çalışmada, "whistleblowing" kavramının Türkçe karşılığı olan "ifşa" kavramını kullanılmasına karar verilmiştir.

Bilgi ifşası, en genel tanımlama ile bir örgütte daha önce çalışmış ya da halen çalışmakta olan kişiler (Near ve Miceli 1985) veya paydaşlar tarafından örgüt içinde bulunanlara ve başka örgütlere zarar vermemesi için (Aktan 2006) yasa d1şı, etik dışı veya kurallara uymayan davranışları 
(Near ve Miceli 1985) yolsuzluk, hukuka aykırılık ya da ihmal niteliği taşıyan eylemlerin (Aydin 2002) ahlaki bir protesto olarak (Chiu 2003) iç ve dış otoritelere bildirilmesidir. Bilgi ifşasının, gönüllülük esasına dayanan, kişisel çıkar gözetmeden, iyi niyetli olarak kamu yararı ve toplum yararı gözetilerek herhangi bir kişi veya kurumdan izin almaksızın bilinçli olarak gerçekleşmiş olması en sık rastlanan özellikleri arasında yer almaktadır. Ayrıca, ifşada bulunan kişinin geçmişte veya şu anda örgütün bilgilerine erişme hakkı bulunan bir kişi olması da olmazsa olmaz koşullar arasında sayılmaktadır (Arslan ve Kayalar 2017: 16). Bilgi ifşa sürecinde ilk aşama, öncelikle örgüt içinde yer alan bir üst yöneticiye başvurmak olmalıdır. Ĕger bildirilen soruna duyarsız kalınırsa örgütte bulunan diğer kademe yöneticilerine başvurulmalı veya örgüt içinde etikle ilgili görevliye ya da örgüt içinde yasa dışı veya etik dışı iddiaları soruşturacak ve rapor edecek ombudsman bürosu'na durum bildirilmelidir. Bu aşamalardan sonra soruna dair herhangi bir şey yapılmadığı durumlarda ise örgüt dişındaki kişi ya da kurumlarla iletişime geçmek düşünülmelidir (Trevino, Nelson 2004'den aktaran Özler, Şahin ve Atalay 2010: 172).

Near ve Micelli (1985: 4) bilgi ifşası sürecini, dört aşamada ifade etmektedir; ilk olarak bilgi ifşasında bulunacak kişinin, gözlemlediği durumun gerçekten yasadışı, ahlakdışı veya kuraldışı olup olmadığına karar vermesidir. İkinci aşama yanlış olduğu düşünülen durumun yetkililere bildirilip bildirilmeyeceğine karar verilmesidir. Üçüncü aşama da karar vermek durumunda kalan ifşanın yapıldığı örgüttür. Örgütün, ifşaya konu olan duruma müdahale edip etmeyeceği kararını vermesidir. Dördüncü aşama, örgütün bilgi ifşasında bulunan kişi ile ilgili vereceği karardır. Bu aşamada, ifşa eden kişi görmezden gelinebilir veya etkisiz hale getirilebilir.

Bilgi ifşası birçok konuda yapılabilmektedir. Üretilen ürünlerde sağlığa zararlı maddeler kullanılmasına rağmen durumun gizlenmesi, yapılan ameliyatlarda normalin üzerinde ölüm olmasına rağmen konunun incelenmemesi, insan hakları, rüşvet, muhasebe kayıtlarında sahtekârlık gibi mali nitelik taşıyan suçlar, çalışan güvenliği gibi insan hakları ihlali, işletme kayıtlarının gerektiği şekilde incelenmemesi, denetimde ihmallerin yaşanması, araştırma sonucunda elde edilen bulgulardan bazılarının görmezden gelinmesi, üretimin gerçekleştiği çevrede su kaynakları kirliliği, hava kirliliği veya radyasyon tehlikesi olması örnek olarak gösterilebilir (Aydın 2002: 85-86). Bilgi ifşa sürecini başlatan kişi İngilizce alanyazında "whistleblower" olarak adlandır1lırken Türkçe literatürde "ifşacı" olarak kullanılmaktadır. İfşacı, çalıştıkları örgütte yaşanan görevi kötüye kullanma veya yetersizlik gibi durumları kapsayan ihmal, istismar veya tehditleri ortaya çıkaran kişilerdir (Ray 2006: 438). İfşa eyleminin gerçekleşmesi sonucu ifşacı terfi, maaş zammı, ikramiye gibi olumlu sonuçlarla karşılaşabileceği gibi ifşa davranışından dolayı örgüt tarafından misillemeye maruz kalma, ücrette kesinti yapılması, ispiyoncu, hain gibi yakıştırmalarda bulunulması, ikili ilişkilerin zayıflaması ve işten çıkarılma gibi olumsuz durumlarla da karşllaşabilmektedir (Arsan ve Kayalar 2017: 18).

İfşa etmenin yol açacağı bazı örgütsel ya da bireysel sorunlara bağlı olarak çalışanların örgüt içinde etik dışı, yasa dışı veya kural dışı durumlarla karşılaştıklarında bu durumu bildirmeleri veya sessiz kalmaları söz konusu olmaktadır. Bu kararda; bireyin kişisel özellikleri ve kültürel değerleri, örgüt yapısı, kültürü ve politikası, yasal düzenlemeler, yönetime duyulan güven, karşılaşılan duruma ait özellikler, topluma verdiği zararın derecesi, yeterli kanitın bulunmaması ve eylemi kime nasıl ileteceğini bilememe gibi konular etkili olmaktadır (Celep ve Konaklı 2012: 67-68). Yapılan çalışmalarda bilgi ifşa etme eyleminin etkenleri şu beş kategori altında toplanmiştır (Hassink, Vries ve Bolle 2007: 29-30): Psikolojik faktörler, kültürel ve etik faktörler, yasal faktörler, misilleme ve yanlış uygulamalardır. Bilgi ifşa davranışı ise ilk kez Park, Rehg ve Lee (2005) tarafından içsel raporlama, dışsal raporlama ve sessiz kalma olarak üç boyutlu olarak ele alınmıştır. Daha sonra başka bir çalışmada, bilgi ifşası resmi/gayri resmi ifşa, isimli/isimsiz ifşa ve örgüt içi/örgüt dışı ifşa olmak üzere farklı üç şekilde ele alınmıştır (Park vd. 2008). Celep ve Konaklı (2012) tarafından yürütülen çalışmada ise 
ifşa konusu içsel bilgi uçurma, dişsal bilgi uçurma, destekleyici bilgi uçurma ve gizli bilgi uçurma şeklinde gruplandırılmıştır. Bilgi ifşa davranışında; bireysel eğilim, örgütsel eğilim, örgüt içi iletişim, işini kaybetme korkusu ve çevresel duyarlılık boyutlarının önemli olduğu, genel olarak bilgi ifşasının yöneticiler tarafından kabul edildiği, yalnızca örgüt içi iletişim boyutunda daha az olumlu algıya sahip oldukları belirlenmiştir. Ayrıca, yönetim düzeyi itibariyle ifşa hakkındaki algıların farklılaştığı da ortaya koyulmuştur (Akoğlan Kozak ve Kayar 2006). Görüldüğü üzere ifşa konusu gerek turizm alanında ve gerekse diğer alanlarda farklı açılarda ele alınmış bir konudur. Etik konusu ile ilgisi ve ikilem yönlü çalışmaların mevcudiyetine ise sonraki başlıkta yer verilmektedir.

\section{ETIK VE ETiK IKILEM}

Yunanca "ethos-ethikos" sözcügünden türetilmiş ve ahlak sistemi, gelenek görenek, karakter, insan davranışı, prensip anlamına gelen etik, kökleri en az 2500 yıl öncesine dayanan bir felsefe dalıdır (Doğan 2008: 180). Etik, insan yaşaminın her alanına etki eden ve hem bireysel hem de toplumsal anlamda istenilen ve olması gereken yaşam şartlarının belirlenmesinde rol oynayan bir kavramdır (Demirhan ve Karahan 2015: 249) ve ahlaki olarak doğru ve yanlış olan inançlar bütününü ifade etmektedir (Cambridge Sözlüğü 2017). Benzer bir bakış açısıyla etik, bireysel ve grupsal davranış ilişkilerinde neyin iyi neyin kötü olduğunu belirleyen ahlaki ilkeler, değerler ve standartlar sistemi olarak tanımlanmaktadır (Hatcher 2004:358). Türk Dil Kurumu da etik kavramını çalışma yaşamı ile ilişkilendirerek, "çeşitli meslek kolları arasında tarafların uyması veya kaçınması gereken davranışlar bütünü" olarak tanımlamaktadır (T.C. Başbakanlık Atatürk Kültür, Dil ve Tarih Yüksek Kurumu Türk Dil Kurumu 2018). Etik, “ahlaksal olanın özünü ve temellerini araştırıp, insanın kişisel ve toplumsal yaşamındaki ahlaksal davranışları ile ilgili sorunları ele alıp incelemektedir" (Akoğlan Kozak ve Güçlü 2006: 22).

İkilem ise "iki önermesi bulunan ve her iki önermenin vargısı olan tasım" veya "insanı isten- meyen seçeneklerden birini, çoğunlukla iki seçenekten birini izlemeye zorlayan sorun veya usa vurma durumu" olarak tanımlamaktadır (T.C. Başbakanlık Atatürk Kültür, Dil ve Tarih Yüksek Kurumu Türk Dil Kurumu 2018). İngilizcede "dilemma" olarak karşılık bulan ikilem, iki şey arasında yapmak zorunda olunan zor bir seçimi ifade etmektedir (Cambridge Sözlügü 2017). Etik ikilem ise ikisi de ahlaki bir ilkeye aykırı olan davranış biçimleri arasından seçim yapılmasinı gerektiren durum olarak tanımlamaktadır (Cambridge Sözlüğü 2017). Etik ikilemde iki veya daha fazla değerin çatışma durumu söz konusudur. Çatışan bu değerlerden birinin korunması durumunda diğeri korunamamaktadır. Bir başka ifadeyle, bir değerin korunabilmesi için diğerinin göz ardı edilmesi zorunluluğu bulunmaktadır (Gartner 1994'ten aktaran Şen 2005: 361).

Son yıllarda turizm, insan haklarının önemli olduğu ve özellikle çocuk, yaşlı, engelli, etnik azınlıklar gibi daha savunmasız grupların da katılımının sağlanmasının teşvik edildiği bir faaliyet alanı haline gelmiştir (Turizmde Global Etik İlkeler). Fakat turizme katılmada bu grupların karşılaştıkları kimi ayrımcılıklar; mevcut küresel ilkeler ile uygulamalar arasındaki bir çelişkiye, hatta ikileme işaret etmektedir (Demir 2011: 763-767). Örneğin, engelli olma durumuna göre yaşanan ayrımcılık gibi. Sektörde çalışma durumunda da ayrımcılık söz konusu olabilmektedir. Bu süreçte işverenlerin, iş verimi ve iş güvenliğini tehlikeye attıkları gerekçesiyle olumsuz tutumlara sahip oldukları tespit edilmiştir (Aracı ve Koçak 2014: 195). Turizm yöneticilerinin, turistlerin kültürel ve dini vecibelerini yerini getirmesine yardımc1 olmaları gerekmektedir. Helâl turizmin böyle bir kolaylık ve farklı bir turizm çeşidi yarattığı söylenebilir. Ancak bu turizmde Müslüman olmayan turistlerin helâl turizm işletmelerine alınmaması prensibi bazı etik sorunları beraberinde getirmektedir. Bir işletmenin sadece belirli bir gruba hizmet vermesi evrensel turizm değerleri ile çelişmekte (Karayılan, Demirkol ve Dinçer 2017: 1198) ve bir etik ikilem yaratmaktadır.

Turizm endüstrisinin doğal çevreye ve yerel halkın sosyo-kültürel değerlerine zarar vermesine karşın, topluma ekonomik kazanç sağlaması

\section{4 - Anatolia: Turizm Araştırmaları Dergisi}


(Aslan ve Kozak 2006: 50) etik sorunları beraberinde getirmektedir. Turizmin gelişmesinde bütün taraflar, doğal çevreyi korumakla yükümlüdür. Kültürel ve doğal çevre, bir taraftan turizmin en önemli kaynakları iken diğer yandan turizmin en önemli olumsuz etkileri de bu alanlar üzerinde olmaktadır. Bu çerçevede konaklama işletmeleri de doğal kaynakları ve kültürel varlıkları kullanırken, onların korunması ve rasyonel kullanımı konusunda gerekli özeni göstermelidir (Türker ve Uçar 2013: 160). Turizm tesislerinin planlanması, mimarisi ve işletilmesi yerel ekonomik ve sosyal dokuya entegre olacak şekilde yürütülmelidir. Turizm altyapısı ve faaliyetleri, ekosistem, bio-çeşitlilik ve vahşi yaşamın korunmasını sağlayacak şekilde hazırlanmalıdır. Yöneticiler, özellikle yatırımcılar, projelerinde turizmin çevre ve doğal yaşama etkisini inceleyen araştırmalara yönelmelidirler (Turizmde Global Etik İlkeler).

Yerel nüfus, turizm faaliyetlerinin ekonomik, sosyal ve kültürel faydalarından, özellikle de turizmin yarattığ 1 doğrudan ve dolaylı istihdamdan yararlanmalıdır. Ancak yerel halkın işgücü olarak tercih edilmesi ilkesi ile çevresel ve sosyokültürel sorunların ortaya çıkması ikilem durumu yaratmaktadır. Dağ turizmi dağlık yörelerde yaşayan nüfus için ekonomik fayda sağlamakla birlikte çok fazla yerli ve yabancı ziyaretçi çekmesinden dolayı ekolojik sistem olumsuz etkilenmektedir (Somuncu 2004: 18). Örneğin, kültürel yozlaşma, çöp, trafik, kalabalık, betonlaşma, doğal kaynakların tahrip olması, mevsimlik fiyat artışları gibi sorunlar yerli halkın turizmi olumsuz algılamasına neden olmaktadır (Türker ve Uçar 2013: 160). Bakıldığında, başta fayda yaratan turizm sektörünün bir dönem sonra olumsuz algılandığı, dolayısıyla yerel halkın da iyi yönetilmeyen bir turizm sistemi hakkında ikilem yaşadığı söylenebilir.

İşletmelerde yaşanan sorunları bildirmenin ne derece ahlaki olduğu kişide bir ikilem yaratmakta ve karasız kalabilmektedir. İşletmelerde ikilemler kişisel ahlaki sorumlulukların çatışmasından kaynaklı olduğu gibi paydaşlar arasındaki sosyal sorumlulukların çatışmasından kaynaklı olarak da ortaya çıkmaktadır. Turizm işletmelerinin hissedarlara, müşterilere, işgörenlere, devlete, rakiplere, tedarikçilere, doğal çevreye, topluma ve bu paydaşlara yeni eklenen medyaya, sivil toplum kuruluşlarına, müşteri sözcülerine, çevreci aktivistlere, finans kurumlarına, bankalara karşı sosyal sorumlulukları bulunmaktadır (Türker ve Uçar 2013: 158). Sosyal sorumluluk kavramının sadece işletmelerin hissedarlarını memnun edecek faaliyetlerde bulunması ile ilgili olmadığı aynı zamanda, diğer paydaşlarının kârının arttırılması ile ilgili faaliyetleri de kapsadığı ifade edilmektedir (Pelit, Keleş ve Çakır 2009: 20). Yöneticilerin hissedarlara karşı kârı arttırmak ve maliyetleri azaltmak gibi sorumlulukları bulunurken diğer paydaşlarına karşı olan sorumluluklarını da yerine getirmelidir. Ancak genellikle hissedarlar ile diğer gruplara olan sorumlulukları arasında bazı ahlaki uygulamalarda ikilem yaşamaktadirlar.

\section{TARTIŞMA VE SONUÇ}

Araştırmalar da bilgi ifşası konusunun; hukuk ve denetim bağlamında incelenerek kavramsal aç1dan ele alındığı ve sadakat, kurumsal sosyal sorumluluk, işten ayrılma niyeti gibi kavramlarla ilişkisinin incelendiği görülmektedir. Ayrıca, bilgi ifşasının ifşacı açısından vicdani rahatlık, kamu açısından şeffaflık ve sorumluluk oluşmasına katkı sağlaması gibi avantajları olduğu belirlenmiştir (Uyar ve Yelgen 2015: 93-94). Otel işletmeleri bağlamında yapılan bir çalışmada ise bilgi ifşa davranışının; bireysel eğilim, örgütsel eğilim, örgüt içi iletişim, işini kaybetme korkusu ve çevresel duyarlılık boyutların da önemli olduğu, genel olarak bilgi ifşasının yöneticiler tarafından kabul edildiği belirlenmiştir (Akoğlan Kozak ve Kayar 2006). Bu araştırma sonrasında doğrudan turizmde ifşayı konu alan bir başka araştırma bulgusuna rastlanamamıştır. Bilgi ifşasının turizm sektöründe ele alınmasındaki bu çekingenlik, konunun hassasiyetine bağlı olarak veri toplamada yaşanacak sıkıntılara ve engellenme kaygısına bağlanabilir. Etik konusu ise turizm ve diğer işletmecilik alanlarında tercih edilen bir araştırma konusu olmuş ve sıklıkla ele alınmıştır. Dünya Turizm Örgütünün Küresel Etik İlkeleri yanında, turizmde etik standartlar, etik kodlar, turizmde meslek 
standartları, uygulamada yaşanan etik sorunlar birçok araştırmaya konu olmuş, bu bağlamda ciddi bir alanyazın oluşurken, sektör yetkililerine de yol gösterici ipuçları sunulmuştur.

Bilgi ifşasının etik olup olmadı ğı da bazı araştırmalarda ele alınmıştır. Aktan (2006) bilgi ifşasının etik bir eylem olduğunu belirtmiş ancak organizasyon dışına ifşa edilmesinin etik olup

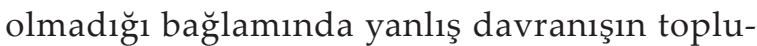
ma maliyeti, organizasyon içindeki yönetime bildirilmiş olması, ifşa sonrası herhangi bir geri bildirim alınmamış olması, yanlış olan eylemin dışarıya ifşa edilmesiyle son bulacağı inancı gibi şartların gerekliliğine işaret etmiştir. Özler, Şahin ve Atalay (2010) tarafından ise bilgi ifşası etik bir süreç olarak ifade edilmiş ve iş etiği, meslek etiği ve işletme etiği ile ilişkili bir kavram olduğu belirtilmiştir. Başka bir çalışmada ise ifşa eylemi, örgüt amaçlarını korumak, örgüt üyelerinin zarar görmesini engellemek ve ahlaki ya da mesleki değerler nedeniyle yapılması durumunda etik bir davranış olarak değerlendirilmesi gerektiği ifade edilmiştir (Celep ve Konaklı 2012). Jensen'in (1987) bilgi ifşası ile etik arasındaki ilişkiyi incelediği çalışmasında yapılan ifşanın etik olup olmadığının belirlenmesinde toplumun değer yargıları, dini inançlar, faydacılık, kişisel çıkarlar, karakteristik özellikler, çevresel ve durumsal faktörlerin önemli olduğu belirtilmiştir. Ray (2006) bilgi ifşasının etik bir davranış olması için nedenlerinin de etik olması gerektiğini belirtmiştir. Lindblom (2007) ise bilgi ifşasının özellikle toplumu ilgilendiren konularda yanlış davranış veya eylemleri yetkili kişi veya kurumlara bildirilmesinin etik olduğunu ifade etmiştir.

$\mathrm{Bu}$ çalışmada ulaşılan başka bir görüntü ise yaşanan etik ikilemlerdir. Yanlış uygulamalara şahit olan kişi çeşitli nedenlerden dolayı bu durumu söyleyip söylememe konusunda kararsızlık yaşamaktadır. Başka bir deyişle, kişiler (çalışan ya da müşteri, yönetici, yerel idareci, yerel halk) bilgi ifşası noktasında bir değer çatışması yaşamakta ve durumu yetkililere bildirme konusunda kararsız kalmaktadır. Kişinin yaşadığ 1 bu ikilem bazen kişisel ve örgütsel değerler arasındaki çatışmadan, bazen de örgütsel sadakat nedeniyle olabilmektedir (Jubb 1999: 79; Lind- blom 2007: 424). Etik ikilem ile doğrudan ilişkili kimi çalışmalar; bu konunun hemşirelik (Utlu 2016), muhasebe (Daştan, Bellikli ve Bayraktar 2015; Kutlu 2008) ve psikolojik danışmanlık (Akfert Kolay 2012) mesleklerinde daha sık yaşandığını, değerler (Kutlu, Güner ve Demirci 2012) ve etik eğilimler ile (Alakavuklar ve Arbak 2008) ilişkili olduğunu ortaya koymaktadır. Bilgi ifşas1 ve etik ikilem turizm sektöründe de kritik bir konu olmasına rağmen, bugüne kadar bu bakış açısıyla ele alınmamıştır. Bu gözden kaçırma aslında, sektörle ilgili güncel bilgi eksikliği yanında, birçok örgütsel davranışın açıklanmasındaki eksikliğe de işaret etmektedir. Etik davranış, sosyal sorumluluk, örgütsel vatandaşlık, örgütsel sessizlik, bireysel davranış gibi birçok davranışın tanımlanmasında sorun bildirme davranışı kabul edilen bir boyuttur. Dolayısıyla ifşa ile ilgili davranışı tanımlamadan, turizmde diğer örgütsel davranışların tanımlanması zor olacaktır. Bu nedenle, çalışmada öncelikle bu iki konunun önemine dikkat çekmek istenmiştir. Turizm alanyazınında yaşanan etik sorunlara sık sık yer verildiği, ancak, bu sorunların giderilmesi için çalışanların nasıl davrandığı, etik olanı yapıp yapmama konusundaki tercihleri bağlamında ciddi bilgi boşlukları olduğu gözlenmiştir. Başka bir ifadeyle, turizmde yaşanan etik ikilem durumu henüz doğrudan herhangi bir araştırmaya konu olmamıştır. Oysa bilgi ifşası konusunda yaşanan çekingenliğin nedenlerinin güncellenmesi bile örgütsel yapı ve çalışanlarla ilgili birçok konu hakkında alanyazına ve sektör yöneticilerine ciddi ipuçları verecektir. Turizm sektöründe yaşanan sorunların ifşasındaki etik ikilemlerin saptanması ise örgütsel yaşamla ile ilgili ortaya at1lan birçok görüşe sağlam dayanak teşkil edecektir. Makalenin işaret ettiği bu sonuca bağlı olarak gelecekte, bu konunun turizm bağlamında farklı araştırmalarda ele alınması önerilebilir.

\section{KAYNAKÇA}

AAkan, P. (2007). Uygulama Açısından İş Etiği Kuralları ve Evrensel Turizm Etiği İlkeleri, Anatolia: Turizm Araştırmaları Dergisi, 18 (1): 7-20.

Akfert, S. K. (2012). Farklı Kurumlarda Çalışan Psikolojik Danışmanların Yaşadıkları Etik İkilemler ile Bu İkilemler Karşısındaki Tutum ve Davranışları, Kuram ve Uygulamada Eğitim Bilimleri, 12 (3): 1791-1812. 
Akoğlan Kozak, M. ve Güçlü, H. (2006). Turizmde Etik: Kavramlar, İlkeler, Standartlar. Ankara: Detay Yayınc1lı.

Akoğlan Kozak, M. ve Kayar, Ç. H. (2006). Örgüt İçi Sorun Bildirme: Otel İşletmelerinde Farklı Yönetim Düzeylerindeki Yönetici Algılamalarına Yönelik Bir Araştırma, III. Lisansüstü Turizm Öğrencileri Kongresi, Çanakkale: Çanakkale Onsekiz Mart Üniversitesi, 598-618.

Aktan, C. C. (2006). Organizasyonlarda Yanlış Uygulamalara Karşı Bir Sivil Erdem, Ahlaki Tepki ve Vicdani Red Davranışı: Whistleblowing, Mercek Dergisi, 1 (13): 1-13.

Alakavuklar O. N. ve Arbak Y. (2008). Ahlaki İkilem Çatışmalarının Yönetiminde Etik Eğilimlerin Rolü. 16. Ulusal Yönetim ve Organizasyon Kongresi, Antalya: İstanbul Kültür Üniversitesi, 701-704.

Aracı, Ü. E. ve Koçak, N. (2014), Dezavantajlı Bireylerin Turizmde İstihdamı: İnsan Kaynakları Yöneticilerinin Alg1, Görüş ve Deneyimlerinin İncelenmesi, Gazi Üniversitesi Turizm Fakültesi Dergisi, 2: 191-205.

Arslan, E. T. ve Kayalar, M. (2017). Kamu ve Özel Sektör Çal1şanlarının İfşa (Whistleblowing) Niyeti: Karşılaştırmalı Bir Analiz, KMÜ Sosyal ve Ekonomik Araştırmalar Dergisi, 19 (32): 15-26.

Aslan, A. ve Kozak, M. (2006). Turizmde Gelişme ve Etik Sorunları: Üniversite Öğrencileri Üzerine Bir Araştırma, Ege Akademik Bakış Dergisi, 1 (6): 49-61.

Aydın, U. (2002). İş Hukuku Açısından İşçinin Bilgi Uçurmas1 (Whistleblowing), Anadolu Üniversitesi Sosyal Bilimler Dergisi, 2 (2): 79-100.

Cambridge Sözlüğü, https://dictionary.cambridge.org/dictionary/ english/ethics, Erişim tarihi: 29 Aralık 2017.

Celep, C. ve Konaklı, T. (2012). Bilgi Uçurma: Eğitim Örgütlerinde Etik ve Kural Dışı Uygulamalara Yönelik Bir Tepki, E-International Journal of Educational Research, 3 (4): 65-88.

Chiu, R. K. (2003). Ethical Judgement and Whistleblowing Intention: Examining the Moderating Role of Locus of Control, Journal of Business Ethics, 43 (1/2): 65-74.

Daştan, A., Bellikli, U. ve Bayraktar, Y. (2015). Muhasebe Eğitiminde Etik İkilem ve Etik Karar Alma Konularına Yönelik KTÜ-İ̈BF Öğrencileri Üzerine Bir Araştırma. $A \dot{I}-$ BÜ-İ̈BF Ekonomik ve Sosyal Araştırmalar Dergisi, 11 (1): 75-92.

Demir, M. (2011). İş Yaşamında Ayrımcılık: Turizm Sektörü Örneği, Uluslararası İnsan Bilimleri Dergisi, 8 (1): 760784.

Demirhan, M. F. ve Karahan, A. (2015). Akademisyenlerin Adalet ve Etik Algılarının Örgütsel Adanmışlıklarına Etkisi, Uşak Üniversitesi Sosyal Bilimler Dergisi, 8 (4): 245 -266 .

Doğan, N. (2008). İş Etiği ve İşletmelerde Etik Çöküş, Selçuk Üniversitesi İktisadi ve İdari Bilimler Fakültesi Sosyal ve Ekonomik Araştırmalar Dergisi, 1 (16): 179-200.

Gerçek, H. (2005). Mühendislikte Etik Sorunların Ele Verilmesi, Madencilik Dergisi, 44 (4): 29-38.

Hassink, H., Vries, M. ve Bollen, L. (2007). A Content Analysis of Whistleblowing Policies of Leading Eoropean Companies, Journal of Business Ethics, 75: 25-44.
Hatcher, T. (2004). Environmental Ethics As An Alternative For Evaluation Theory In For Profit Business Context, Evaluation And Program Planning, 27: 357-363.

Hersh, M. A. (2002). Whistleblowers-Heroes or Traitors?: Individual And Collective Responsibility For Ethical Behavior, Annual Reviews in Control, 26: 243-262.

Jensen, J. V. (1987). Ethical Tension Points in Whistleblowing, Journal of Business Ethics, 6 (4): 321-329.

Jubb, P. B. (1999). Whistleblowing: A Restrictive Definition and Interpretation, Journal of Business Ethics, 21 (1): 7794.

Karayılan E., Demirkol Ş. ve Dinçer M. Z. (2017). Turizm Akademisyenlerinin Helal Turizm Prensiplerinin Uygulanabilirliğine İlişkin Görüşlerinin Değerlendirilmesi. 1. Uluslararası Helal Turizm Kongresi, Antalya, 1193-1203.

King III, G. (1999). The Implications Of An Organization's Structure On Whistleblowing, Journal of Business Ethics, 20 (4): 315-326.

Kutlu, H. A. (2008). Muhasebe Meslek Mensupları ve Çalışanlarının Etik İkilemleri: Kars ve Erzurum İllerinde Bir Araştırma, Ankara Üniversitesi Siyasal Bilgiler Fakültesi Dergisi, 63 (2): 143-170.

Kutlu, H. A., Güner, M. ve Demirci, N. S. (2012). Etik İkilemden Çıkışta Kişisel Değerin Rolü: Muhasebe Meslek Mensupları Üzerinde Bir Uygulama, 1. Uluslararası Muhasebe ve Finans Sempozyumu, Gaziantep, 733-746.

Lindblom, L. (2007). Dissolving The Moral Dilemma of Whistleblowing, Journal of Business Ethics, 76: 413-426.

Near, J. P. ve Miceli, M. P. (1985). Organizational Dissidence: The Case of Whistle-Blowing, Journal of Business Ethics, 4: 1-16.

Özler, D. E., Şahin, M. D. ve Atalay, C. G. (2010). Teorik Bir Çerçevede Whistleblowing Etik İlişkisi, Eskişehir Osmangazi Üniversitesi Sosyal Bilimler Dergisi, 11 (2): 169194.

Park, H., Blenkinsopp, J., Oktem, M.K. ve Omurgonulsen, U. (2008). Cultural Orientation and Attitudes Toward Different Forms of Whistleblowing: A Comparison of South Korea, Turkey, and the U.K, Journal of Business Ethics, 82 (4): 929-939.

Park, H., Rehg, M.T. ve Lee, D. (2005). The Influence of Confucian Ethics and Collectivism on Whistleblowing Intention: A Study of South Korean Public Employees, Journal of Business Ethics, (58): 387-403.

Pelit, E., Keleş, Y. ve Çakır, M. (2009). Otel İşletmelerinde Sosyal Sorumluluk Uygulamalarının Belirlenmesine Yönelik Bir Araştırma, Yönetim ve Ekonomi Dergisi, 16 (2): 19-30.

Ray, S. L. (2006). Whistleblowing and Organizational Ethics, Nursing Ethics, 13 (4): 438-445.

Somuncu, M. (2004). Dağcıllk ve Dağ Turizmindeki İkilem: Ekonomik Yarar ve Ekolojik Bedel, Coğrafi Bilimler Dergisi, 2 (1): 1-21.

Şen, M. L. (2005). Kamu Görevlilerini Yoldan Çıkaran Bubi Tuzakları: Hediye ve Kişisel Kullanım Amacıyla Yap1lan Bağışlar. Siyasette ve Yönetimde Etik Sempozyumu, Sakarya: Sakarya Üniversitesi, 361-377. 
T.C. Başbakanlık Atatürk Kültür, Dil ve Tarih Yüksek Kurumu Türk Dil Kurumu, http://www.tdk.gov.tr/index.php?option=com_gts $\mathcal{E}$ arama $=$ gts $\mathcal{E} g u i d=T D K$. GTS.5a185a19d0d317.91975467, Erişim tarihi: 6 Ocak 2018.

Turizmde Global Etik İlkeler, http://ethics.unwto.org/sites/all/files/docpdf/turkey.pdf, Erişim tarihi: 11 Ocak 2018.

Türker, N. ve Uçar, M. (2013). Konaklama İşletmelerinin Sos- yal Sorumlulukları, İşletme Araștırmaları Dergisi, 5 (3): 155-183.

Utlu, N. (2016). Hastane Ortamında Hemşirelerin Etik Yaklaşımı ve Etik İkilemler, İstanbul Aydin Üniversitesi Dergisi, 29: 17-35.

Uyar, S. ve Yelgen, E. (2015). Bilgi İfşası (Whistleblowing) ve Denetim, Yönetim ve Ekonomi Araştırmaları Dergisi, 13 (1): 85-106.

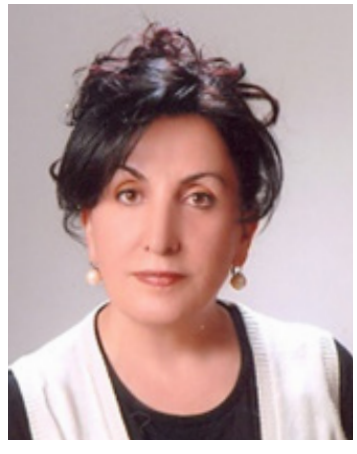

\section{Meryem AKOĞLAN-KOZAK}

Ege Üniversitesi İşletme Fakültesi Aydın Turizm İşletmeciliği ve Otelcilik Yüksekokulu'ndan 1980 yılında mezun oldu. 1987 yılında Çukurova Üniversitesi Turizm İşletmeciliği ve Otelcilik YO' da akademik hayata başladı. Yüksek lisans derecesini 1991 yılında Hacettepe Üniversitesi Turizm İşletmeciliği ABD'den, doktora derecesini ise 1996 yılında Gazi Üniversitesi Turizm İşletmeciliği Eğitimi ABD’den aldı. Doçentlik unvanını 1999 yılında Turizm Bilim Dalından aldı. 2005 yılında Profesörlüğe atandı.1993 yılından bu yana Anadolu Üniversitesi'nde görev yapmaktadır. Anadolu Üniversitesi'nde önce MYO'da sonrasında, Turizm ve Otel İşletmeciliği YO' da görev yaptı. 2011 yılından bu yana İşletme Fakültesi Konaklama İşletmeciliği Bölümü'nde görev yapmaktadır. Kat Hizmetleri Yönetimi, İnsan Kaynakları Yönetimi, Genel Turizm, Otel Yönetimi, Turizmde Etik, Özel İlgi Turizmi gibi çok sayıda kitapların yazarı olup, on kitabın da editörüdür. Ayrıca, alanında çok sayıda makalesi ve bildirisi bulunmaktadır.

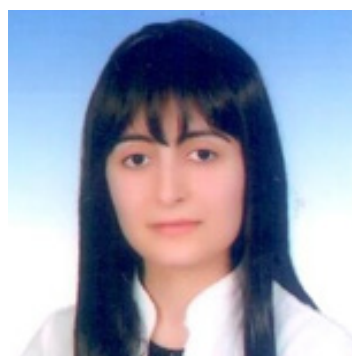

\section{Sibel ŞAHIN}

Atatürk Üniversitesi, Erzurum Meslek Yüksekokulu Turizm ve Otel İşletmeciliği ön lisans programından mezun oldu (2010). Devamında, Dikey Geçiş sınavına girerek Atatürk Üniversitesi, Turizm İşletmeciliği ve Otelcilik Yüksekokulu, Konaklama İşletmeciliği Bölümü'nü kazandı ve 2013 yılında mezun oldu. Yüksek lisans derecesini Atatürk Üniversitesi, Turizm İşletmeciliği ve Otelcilik Anabilim Dalı'ndan aldı (2016). Anadolu Üniversitesi'nde Araştırma Görevlisi olarak mesleki yaşamını sürdürmekte ve Turizm İşletmeciliği Anabilim Dalı'nda doktora eğitimine devam etmektedir. 